\title{
Analysis of Working Time at the Test Site of Southwest Offshore Wind Project in Korea Based on Weather Window 기상조건에 따른 서남해 해상풍력 실증단지 작업시간 분석
}

\author{
Min Suek Kim*, Ji Young Kim*, Ji Yeong Kwak* and Keum Seok Kang* \\ 김민석* • 김지영* • 곽지영* • 강금석*
}

\begin{abstract}
As a preparation process for successful establishment of demonstration offshore wind farm, analyses have been made for working time at the construction site where working time is defined as the time available for marine operation to take place under given weather conditions. Data used are hourly wave and wind data from met mast, HeMOSU-1, and 3 hour numerical model data from Korea Meteorological Administration (KMA). Seasonal results show the minimum working time during winter and moderate during autumn and spring. The most working time was seen during summer on average. Monthly analyses show the most working time in May, June, and August which was higher than the working time in July and September. Working time reaches at steady state and no significant change was seen above wave height of $1.5 \mathrm{~m}$ and wind speed of $8 \mathrm{~m} / \mathrm{s}$.
\end{abstract}

Keywords : Offshore wind farm, working time, weather window

요 지 : 서남해 해상풍력 실증단지 건설의 기초단계로 실증단지 예정부지에서 해상작업가능시간을 산정하고 분석하 였다. 활용 자료로는 해모수 기상타워의 해양 및 기상자료와 기상청 수치모델 자료이다. 해상작업이 가능한 파고와 풍속 기준을 선정하고 기준별 작업시간을 산정한 결과 계절적으로는 고파랑이 지나가는 겨울의 작업시간이 봄, 가 을보다 적은 것으로 나타났고 여름의 경우 작업시간이 가장 많은 것으로 나타났다. 그러나 월별로는 7,9월보다 5,6,8 월에 가장 많은 작업시간이 나타났다. 그리고 파고 $1.5 \mathrm{~m}$ 와 풍속 $8 \mathrm{~m} / \mathrm{s}$ 이상의 기상조건에서는 파고와 풍속이 증가 하더라도 작업시간은 크게 변하지 않는 것을 확인할 수 있었다.

핵심용어 : 해상풍력, 작업시간, 기상조건

\section{Introduction}

\subsection{Background and purpose}

In recent years, there are continuously growing concerns for environment and various researches and policies are made to accomplish various goals like reducing greenhouse effect, control sea level rise, production of renewable energy, and so on. In the energy sector, environmental catastrophe has been realized through the earthquake in Japan which hit the nuclear power plant causing not only numerous casualties but ongoing effects concerned with the exposure to radioactive materials. After such catastrophe, energy production from renewable resources are encouraged and offshore wind farm is one of many alternatives.

For offshore wind farm, operations and maintenance cost and the project's feasibility should be assessed in prior to be used as renewable energy source and working time is one of many factors considered in the establishment stage. Working time is defined as the time available for marine operation to take place under given weather window and weather window is the criteria under which marine operations can be carried out. In this study, working time is analyzed based on weather window considering wave height and wind speed at demonstration offshore wind farm site in South Western part of Korea.

\subsection{Recent studies}

There had been various studies concerned with the economical evaluation of the construction projects and are quite advanced but for marine operations, it had been hindered due to dependency on weather conditions. Braam and Eecen(2005) developed cost estimator model and had put

*KEPCO Research Institute (Corresponding author: Min Suek Kim, KEPRI, 105 Munji-ro Yuseong-gu, Daejeon, 34056, Korea, Tel: +82-42-8655213, Fax: +82-42-865-5414, thegreatkim@kepco.co.kr) 
much emphasis on weather conditions such as waves and wind. In their study, weather window under which maintenance actions can be performed was selected i.e. significant wave height(hs) and wind speed (v) are below the maximum values, and waiting time was calculated based on stochastic process for long term prediction.

In Korea, Jung et al.(1997) used the wave data in Pohang harbor to calculate the downtime. In their study, waves with different wave periods and types were used and their effects on downtime were calculated. Kim et al.(2012) analyzed the marine operation working time using wind and wave data. In their study, working time is sought under selected conditions for four months. In their final remarks, they commented that wind and wave data for long period of time should be used because seasonal difference for climate is significant in Korea.

\section{Methodology}

\subsection{HeMOSU-1}

Government has a plan to establish demonstration wind farm in the south western part of Korea and in preparation for successful establishment, KEPCO Research Institute has been operating offshore met mast, HeMOSU-1 since 2011. The structure and location of HeMOSU is shown in Fig. 1 and Fig. 2.

\subsection{Data}

Data used in this study are the observation data from HeMOSU-1 (wind and wave data for 2014) and numerical

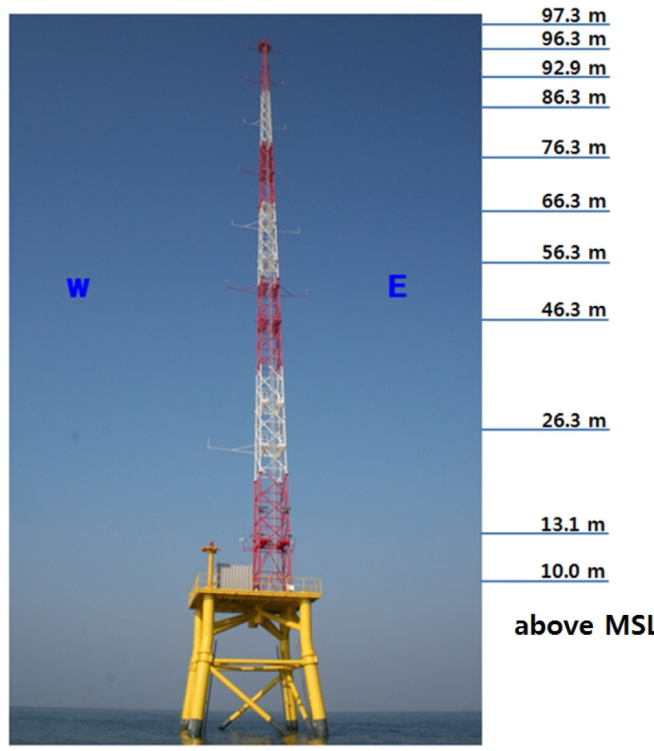

Fig. 1. Structure of HeMOSU-1 and measurement positions. model data from KMA (Korea Meteorological Administration) from 2009 to 2014. HeMOSU-1 has got instruments at different heights to enhance the accurate simulation of wind, wind turbine activities, and wave/tides and in this study, working time is calculated based on wave height and wind speed only. Wave is measured at the base of HeMOSU-1 and wind gauge located at the height of $26 \mathrm{~m}$ is used. For the numerical model data from KMA, wind data is from UM(Unified Model) model at $10 \mathrm{~m}$ above the sea surface and wave model is from Wavewatch III. Since the height from which wind speed were measured are different, that from HeMOSU-1 was adjusted to $10 \mathrm{~m}$ above the surface using power law. For both models, data are 3-hour data from January 2009 to December 2014.

\subsection{Method}

Weather window, popularly used for DOWEC(Dutch Offshore Wind Energy Converter) in 2002, defines maximum wind speed and waves under which marine operations can be carried out. In Korea, regulations and industrial safety standard(2006) provides criteria that all industrial activities should follow and according to this, the crane operation should take place under the wind speed of $20 \mathrm{~m} / \mathrm{s}$ but it is restricted for use on ground. For marine operations, there is no clear standard but different criteria exist and of these, we should be able to figure out which fits best for this study. Crane ship used in marine operation has got criteria that it can operate, with anchor on, with maximum significant wave height of up to $2.5 \mathrm{~m} \sim 3.0 \mathrm{~m}$. For barge, the regulation restricts marine operation when significant wave

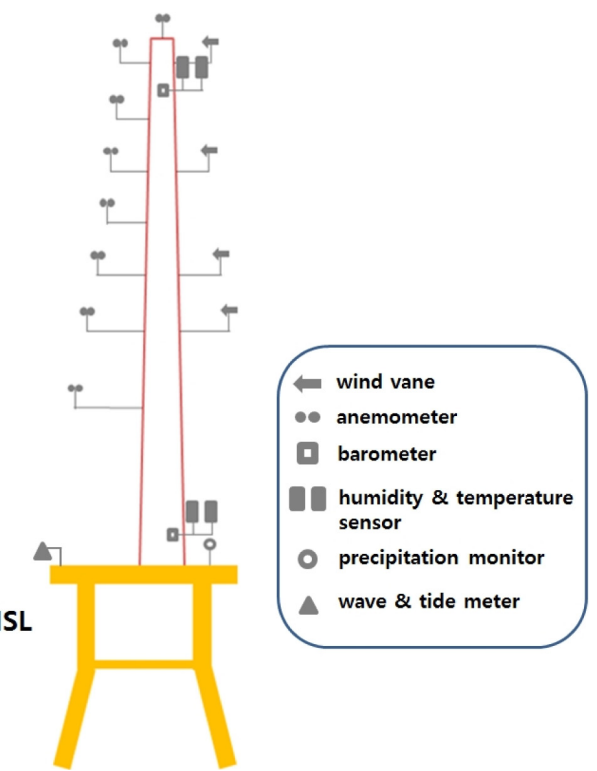




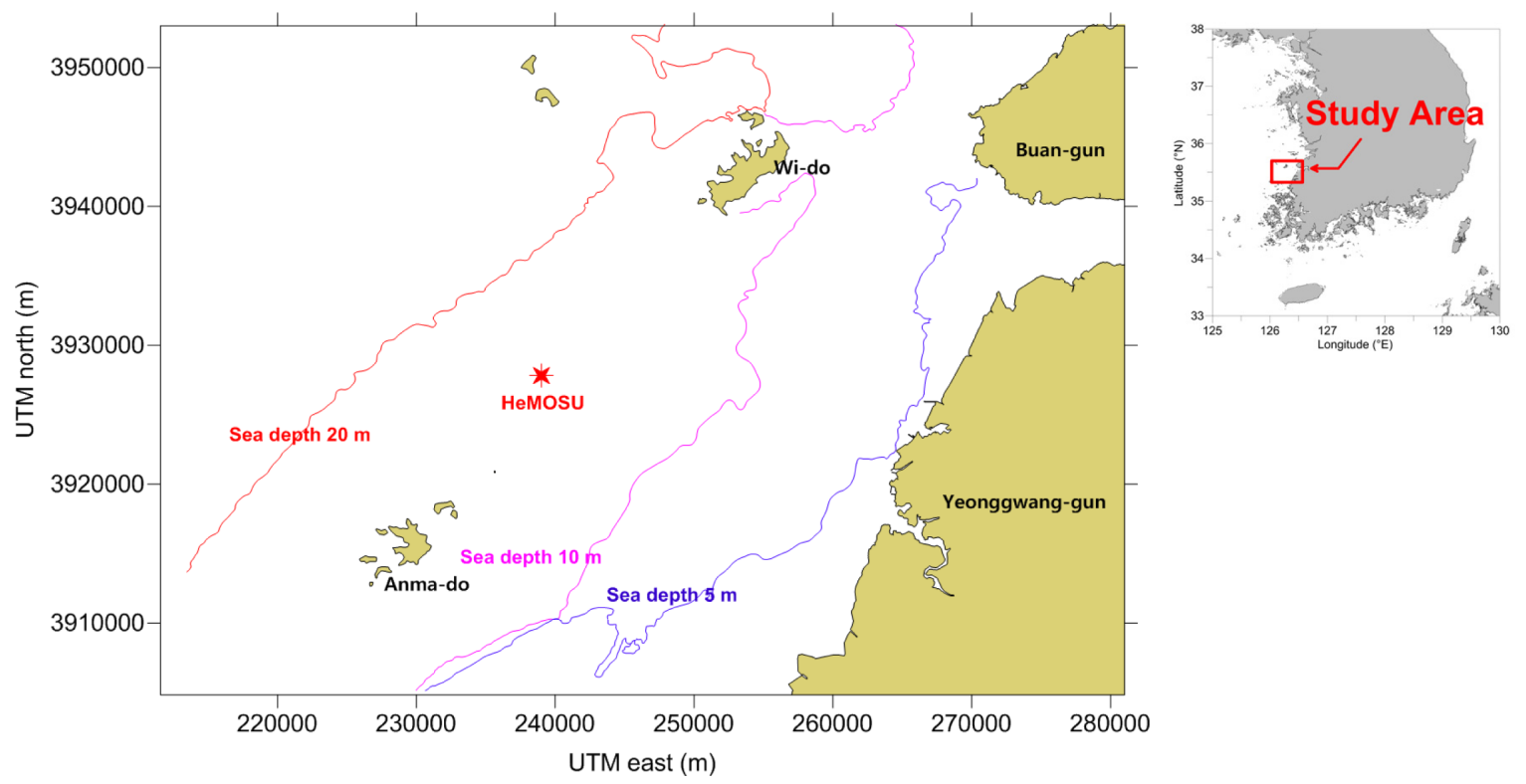

Fig. 2. Location of HeMOSU-1.

Table 1. Test cases for weather window, wave_case(left) and wind_case (right)

\begin{tabular}{cc}
\hline \hline & $\mathrm{H}_{\mathrm{s}}(\mathrm{m})$ \\
\hline Wave_case1 & 0.5 \\
Wave_case2 & 1.0 \\
Wave_case3 & 1.5 \\
Wave_case4 & 2.0 \\
Wave_case5 & 2.5 \\
\hline Wind_case1 & $\mathrm{V}(\mathrm{m} / \mathrm{s})$ \\
\hline Wind_case2 & 5 \\
Wind_case3 & 8 \\
Wind_case4 & 10 \\
Wind_case5 & 12 \\
\hline
\end{tabular}

height and surface wind speed are over $2 \mathrm{~m}$ and $15 \mathrm{~m} / \mathrm{s}$ respectively. Considering these criteria and standards mentioned above, maximum significant wave height and wind speed for weather window used in this study are $2.5 \mathrm{~m}$ and $15 \mathrm{~m} / \mathrm{s}$ respectively. With the weather window, 5 cases for wave and wind are selected and total combination of 25 cases were used in this study, Test cases for weather window is shown in Table 1. Note that through out this study, working hour is calculated with weather window during 08:00 to 18:00 KST.

\section{RESULTS}

\subsection{Working time in 2014}

HeMOSU-1 wave and wind data were analyzed and 25
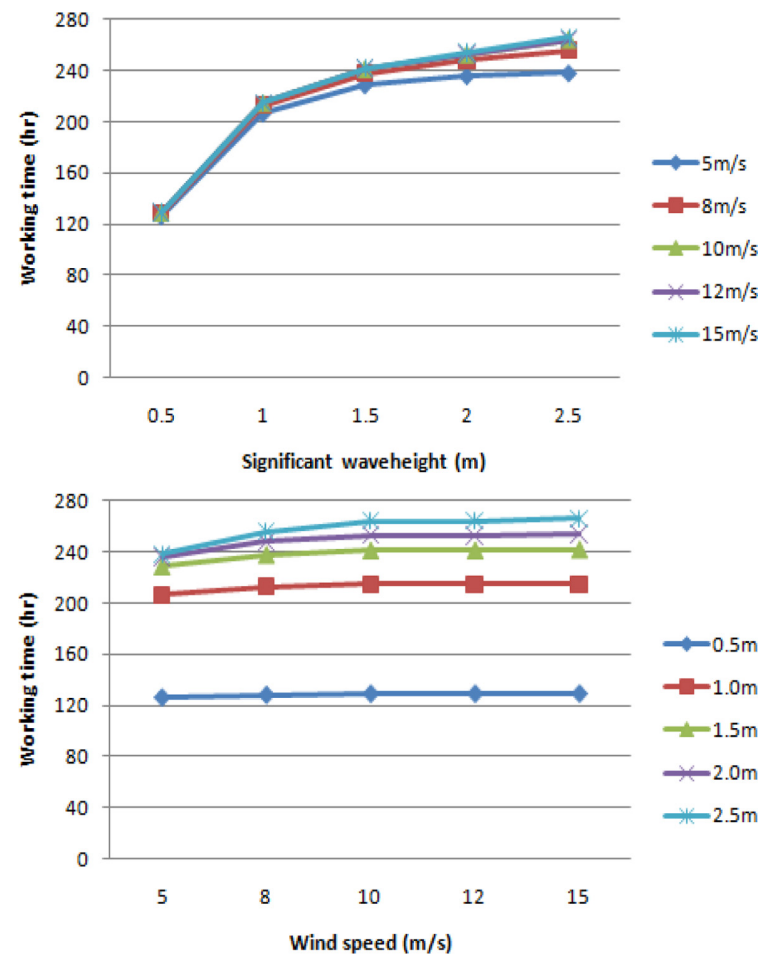

Fig. 3. Graph of working time versus significant wave height(left) and wind speed(right).

cases were chosen from 5 different wave and wind cases, and the working time for each case are plotted in Fig. 3.

As it is seen in the graph, working time increases as significant wave height increases and shows very small increase as wind speed increases. As the significant wave height and wind speed approaches to maximum level, working time increases but it finally reaches steady state where further increase in wave height or wind speed does not guarantee more working time. In Fig. 3 left, gradients 

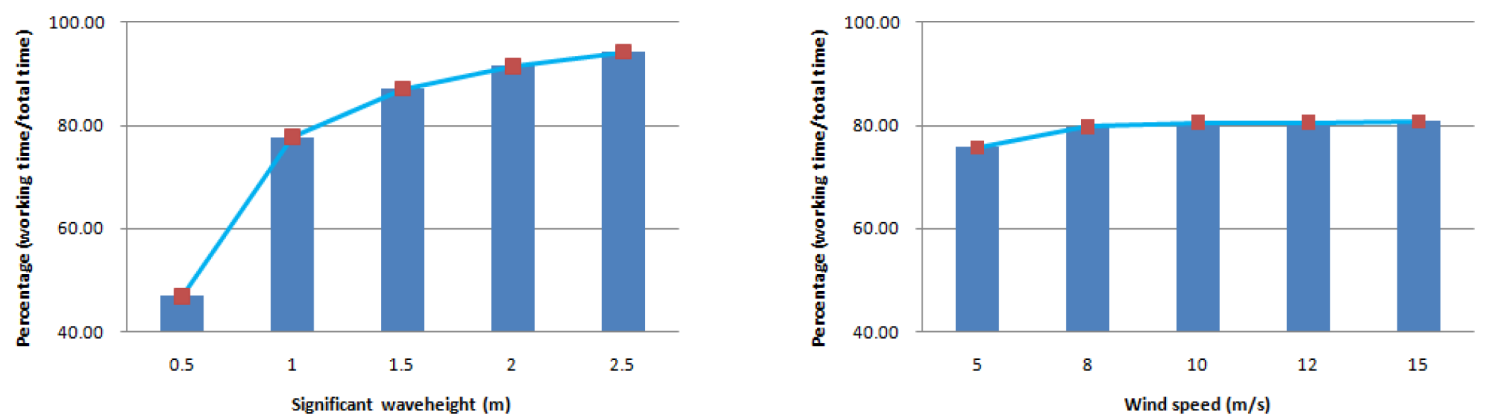

Fig. 4. Percentage of working time for significant wave height(left) and wind speed(right).

Seasonal working time for $\mathrm{v}=8 \mathrm{~m} / \mathrm{s}$

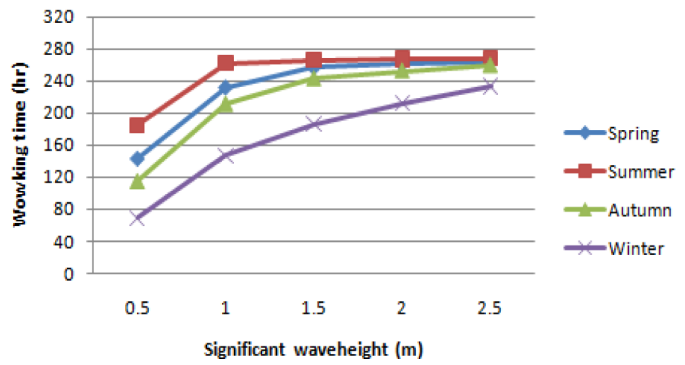

Seasonal working time for $\mathrm{v}=10 \mathrm{~m} / \mathrm{s}$

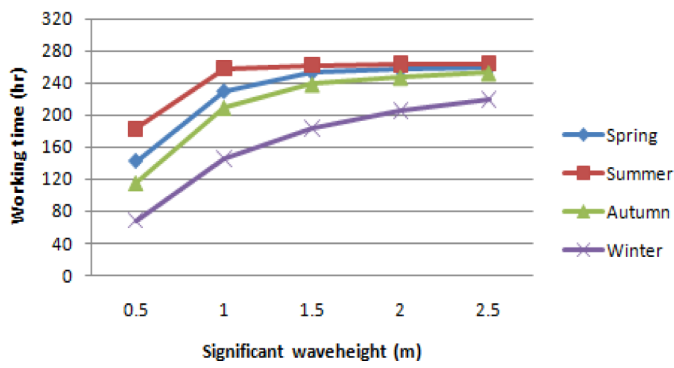

Fig. 5(a). Seasonal working time for $v=8 \mathrm{~m} / \mathrm{s}($ left $)$ and $v=10 \mathrm{~m} / \mathrm{s}$ (right).

Seasonal working time for $h \mathrm{~s}=1.5 \mathrm{~m}$

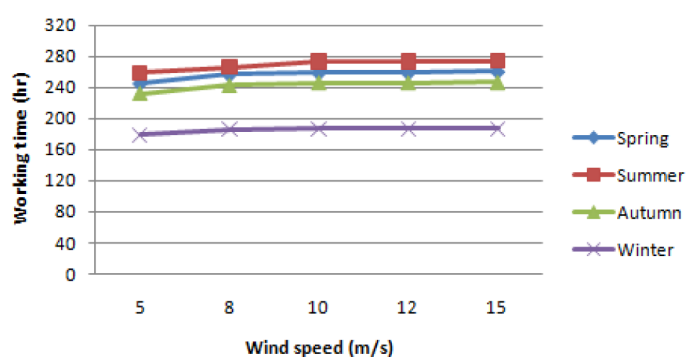

Seasonal working time for $\mathrm{hs}=\mathbf{2 . 0 \mathrm { m }}$

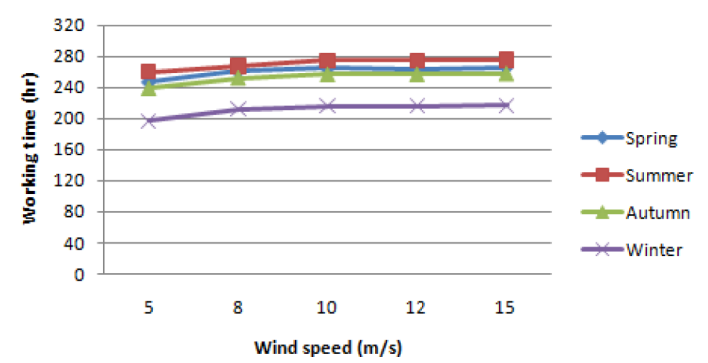

Fig. 5(b). Seasonal working time for $\mathrm{hs}=1.5 \mathrm{~m}$ (left) and hs $=2.0 \mathrm{~m}$ (right).

seem to flatten at significant wave height of $1.5 \mathrm{~m}$ for almost all wind speed and at wind speed of $8 \mathrm{~m} / \mathrm{s}$, gradient seems to flatten for the graph in the right. Fig. 4 shows percentage of working time per total maximum possible working hours.

Total maximum working hour used is 10 hours for each day(from 08:00 to 18:00 as mentioned earlier) and is multiplied by total days in a month. As noted in Fig. 3, it is also significant that percentage gradually increases up to a point above which percentage increase seem to reach steady state. As far as O\&M is concerned, most rational wind speed and significant wave height under which both safety and working time are assured should be set and results in Fig. 3 and Fig. 4 can be used.

Korea is characterized by clear seasonal difference in weather and therefore seasonal working time is important for O\&M. In the previous results, significant wave height of $1.5 \mathrm{~m}$ and wind speed of $8 \mathrm{~m} / \mathrm{s}$ looks to be a point where working time reaches steady state and therefore, seasonal working time is plotted for 2 significant wave height $\operatorname{cases}(1.5 \mathrm{~m}$ and $2.0 \mathrm{~m})$ and 2 wind speed cases $(8 \mathrm{~m} / \mathrm{s}$ and $10 \mathrm{~m} / \mathrm{s})$. It is shown in Fig. 5.

All the seasons are set to be 3 months long where spring starts from March. Since HeMOSU-1 data is only for 2014, January and February along with December were regarded as winter. In all cases in Fig. 5, winter shows the least working time probably due to monsoon characterized by high wind speed and wave height. Patterns for spring and autumn are quite similar for significant wave height and for wind speed, spring shows slightly longer working time than autumn. For summer, it showed the most working time despite the fact that typhoons usually attack during summer. Fig. 6 shows average significant wave height and wind speed from January to December 2014 and it is shown 

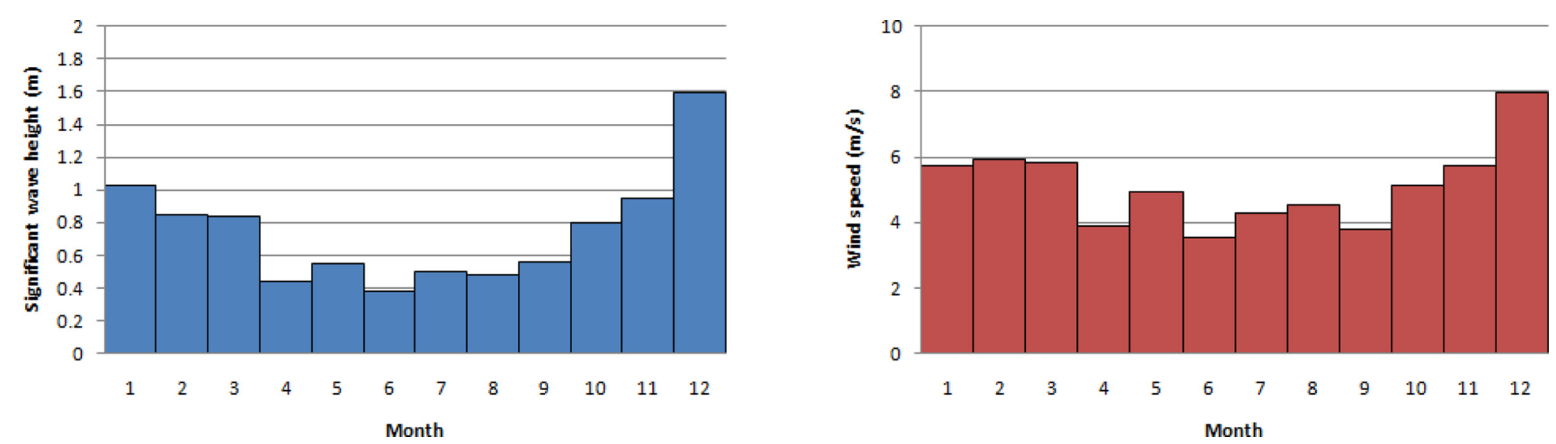

Fig. 6. Average significant wave height (left) and wind speed (right) for 2014.

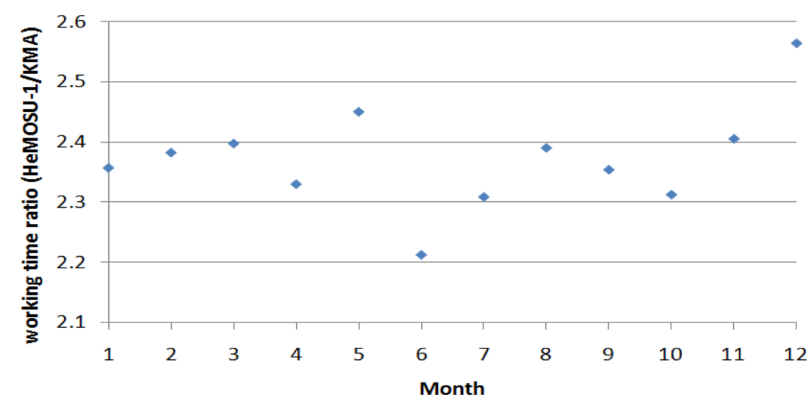

Fig. 7. Monthly working time ratio of 1-hour HeMOSU-1 and 3hour KMA data.

clearly that in 2014, high wind and waves were not seen during summer but are seen during winter. The fact that the test site is located far from typical typhoon path might have brought up the occurrence of high wind and waves not seen in this site during summer.

\subsection{Historic weather data}

3-hour wind and significant wave height from KMA for period of 2009 to 2014 were used and the same criteria for calculation of working time was applied. Since there are complete two sets of data in 2014,they were compared to get the linear multiplier $M$ that relates the 3-hour and 1-hour data. Fig. 7 shows the monthly ratio of working time for 1hour HeMOSU-1 data and 3-hour KMA data.

The linear multiplier was calculated for each month were used to get the corrected working time for 3-hour KMA data in 2014. To evaluated two data, Index of Agreement (IoA) was used which is defined as;

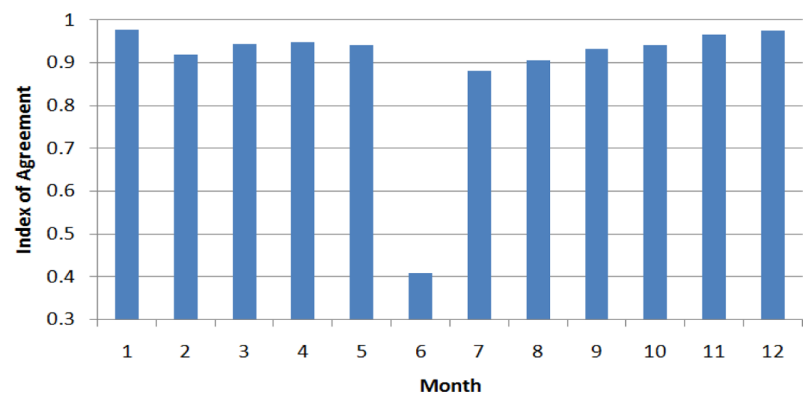

Fig. 8. Monthly Index of Agreement between KMA and HeMOSU-1 data.

$$
I o A=1-\frac{\sum_{i=1}^{n}\left(M_{i}-O_{i}\right)^{2}}{\sum_{i=1}^{n}\left(\left|M_{i}-\bar{O}\right|+\left|M_{i}-\bar{M}\right|\right)^{2}}
$$

where $O=$ observation data, $M=$ model data. The closer the IoA gets to 1 , the more the accuracy of the model data compared to observation data. Monthly IoA was calculated and all other months show values greater than 0.85 except June which shows IoA of about 0.4 but the average value of 0.89 means that the working time calculated from the model generally shows good agreement with the observation data. Fig. 8 shows the monthly IoA for 2014 .

3-hour KMA wind speed and significant wave height for period of 2009 to 2014 are used to calculate working time. Fig. 9 shows monthly average working time from 2009 to 2014. Note that 1-hour data are used for 2014.

It can be seen in Fig. 9 that the working time gradually

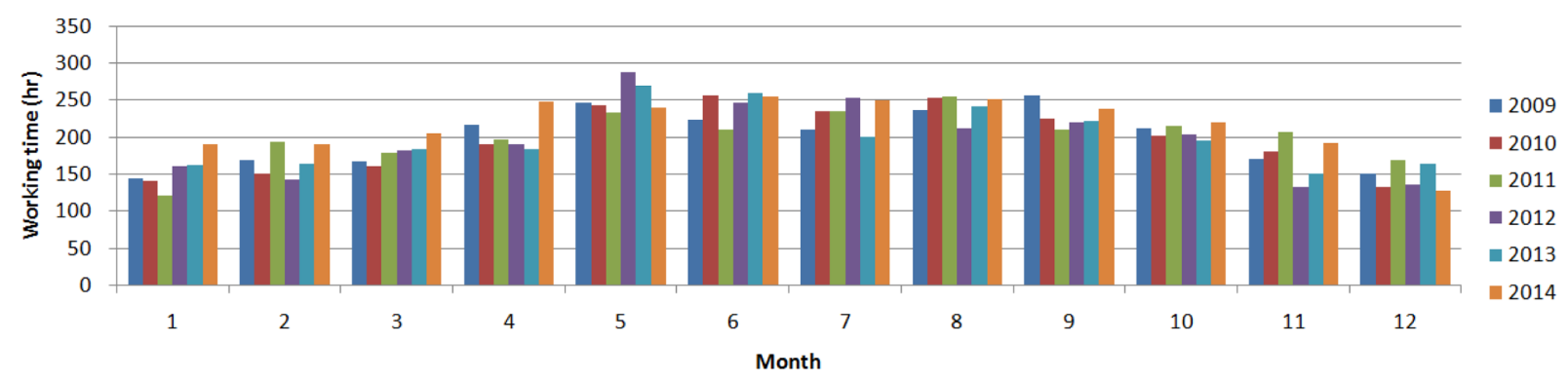

Fig. 9. Monthly average working time from 2009 to 2014 . 
increases from winter to spring and reaches maximum during summer and gradually reduces approaching winter. Average of the data for five years show that most working time was seen during May and June followed by August. The effect of typhoon may have been reduced because the duration and magnitude of the typhoon that attacked Korea was not as big as monsoon high wave and wind during winter and also the test site located far from the major typhoon path.

\section{CONCLUSION}

The working time for demonstration offshore wind farm was calculated using the wind and wave data from HeMOSU-1 and KMA data. The result shows that there was no significant increase in working time for wave height and wind above $1.5 \mathrm{~m}$ and $8 \mathrm{~m} / \mathrm{s}$ respectively. Simultaneous occurrence of two events are rarely seen in the test site which means that most of the wind and wave data are below these values.

Seasonal working time was analyzed and result corresponds with characteristics of the wind and wave data having higher values during winter and lower values during summer. Monthly data shows that working time was at its maximum during May followed by June and August. The gradient of working time increases rapidly from April to June and reaches steady state during summer and decrease starts in September. These results are caused by weather conditions considering only wind and wave and if other weather conditions such as temperature and rainfall are considered, working time during summer may have been reduced.

In the future, more observation data are needed to correctly calculate the linear multiplier and comparison with the weather data should be carried out. Wind and wave data are the major factors influencing weather window but other factors like temperature, rainfall should be considered and reanalyzed which would ensure more realistic working time calculation.

\section{Acknowledgement}

This work was supported by the New \& Renewable Energy of the Korea Institute of Energy Technology Evaluation and Planning (KETEP) grant funded by the Korea government Ministry of Trade, Industry and Energy. (No. 20143010021800, Development and Demonstration Study of Industry-fusion Facilities at the Marine Space of Offshore Wind Farm)

\section{References}

Braam, H. and Eecen, P.J. (2005). Assessment of wind and wave data measured at IJmuiden Munitiestortplaats. "Operation and Maintenance" consortium.

Jung, W.M., Oh, S.B., Chae, J.W. and Kim, S.I. (1997). Analysis of the wave-induced downtime for Pohang New Harbor. Journal of Korean Society of Coastal and Ocean Engineers, 9(1), 24-34 (in Korean).

Kim, J.K., Kim, J.Y. and Lee, J.S. (2012). Analysis on Offshore Working Time of Demonstration Offshore Wind Farm in the Southern Part of West Sea. Korea Wind Energy Association.

O\&M aspects of the 500MW offshore wind farm at NL7, DOWEC project report, 2002.

Regulations on industrial safety standards, Ministry of Labor, 2006.

Received 9 Septmeber, 2015

Revised 7 October, 2015

Accepted 8 October, 2015 